\title{
Türkiyenin Değişen İkliminde Isıtma ve Soğutma Gün Derecelerinin Gelecek Projeksiyonları
}

\author{
Future Projections of Heating and Cooling Degree Days in a Changing Climate of Turkey
}

\author{
Nazan AN ${ }^{1,2}$ (i) , MustafaTufan TURP ${ }^{1,2}$ (i) , Abdullah AKBAŞ⿻̧, ${ }^{2,3}$, Ömer ÖZTÜRK ${ }^{4}$ \\ Mehmet Levent KURNAZ ${ }^{\star 2,5}$ (i) \\ ${ }^{1}$ Boğaziçi Üniversitesi, Çevre Bilimleri Enstitüsü, Çevre Bilimleri Anabilim Dall, 34342, İstanbul, Türkiye \\ ${ }^{2}$ Boğaziçi Üniversitesi, İklim Değişikliği ve Politikaları Uygulama ve Araştırma Merkezi, 34342, İstanbul, Türkiye \\ ${ }^{3}$ Ardahan Üniversitesi, Insani Bilimler ve Edebiyat Fakültesi, Coğrafya Bölümü, 75000, Ardahan, Türkiye \\ ${ }^{4}$ Ankara Üniversitesi, Sosyal Bilimler Enstitüsü, Sosyal Çevre Bilimleri Anabilim Dall, 06560, Ankara, Türkiye \\ ${ }^{5}$ Boğaziçi Üniversitesi, Fen-Edebiyat Fakültesi, Fizik Bölümü, 34342, İstanbul, Türkiye
}

Öz

İklim değişikliğinin etkisiyle 1sıtma ve soğutmaya bağlı gelecekteki enerji talebi ihtiyacında oluşabilecek değişikliklerin öngörülmesinde gün derecelerinden faydalanılması en pratik yöntemlerden biri olarak ortaya çıkmaktadır. Bu çalışmada günümüzdeki gibi yoğun sera gazı emisyonunu içeren RCP8.5 senaryosuna göre Türkiye'de iklim değişikliğiyle birlikte gelecekte 1sıtma ve soğutma gün derecelerinde nasıl bir değişim olacağı öngörülmüştür. Bu amaçla RegCM bölgesel iklim modeli kullanılarak elde edilen yüksek çözünürlüklü sıcaklık değerleri ile hesaplanan 1sıtma ve soğutma gün derece değerleri 2016-2035 ve 2046-2065 gelecek dönemleri için 1981-2000 referans dönemine göre kıyaslanmıştır. Buna göre, 1sıtma gün derece sayılarında tüm ülke genelinde bir azalma ve soğutma gün derece sayılarında ise genel olarak bir artış olacağı öngörülmüştür. Isıtma gün derece sayılarındaki bu azalmanın ve soğutma gün derece sayılarındaki bu artışın 20462065 döneminde 2016-2035 dönemine kıyasla daha fazla olacağı sonucuna varılmıştır. Çalışma sonucuna göre, seçilen iller kapsamında 1sıtma gün derecelerinde her iki gelecek periyodu için en fazla azalış olacağı öngörülen iller sırasıyla; Sivas, Kayseri, Kahramanmaraş ve Mersin; soğutma gün derecelerinde en fazla artış olacağı öngörülen iller sırasıyla; 2016-2035 gelecek periyodu için Şanlıurfa, Diyarbakır, Adana, Manisa; 2046-2065 gelecek periyodu için Şanlıurfa, Diyarbakır, Adana ve Hatay olarak ortaya çıkmaktadır. Bu sıralamada dikkat çeken nokta, soğutma gün derecesinde 2016-2035 gelecek periyodunda en fazla artışın öngörüldüğü dördüncü il olan Manisa’nın yerine 2046-2065 gelecek periyodunda Hatay’ın yer almasıdır. Ayrıca, bu çalışma, Türkiye için en yüksek çözünürlüklü iklim model çıktılarını kullanarak 1sıtma ve soğutma gün derecelerindeki muhtemel değişimleri araştıran ilk çalışmadır.

Anahtar Kelimeler: Isıtma ve soğutma gün dereceleri, İklim değişikliği, Türkiye için iklim projeksiyonları, İklim modellemesi.

\begin{abstract}
Climate change and possible changes in the severity and frequency of related extreme climate events are expected to affect future energy demand. These changes indicate warmer and cooler climatic conditions. Warmer or cooler climates will bring about changes in warming and cooling needs as well. Accordingly, it is one of the most practical methods to take advantage of the degree days to foresee the possible changes in the future energy demand depending on heating and cooling due to the effects of climate change. More extreme temperatures or extreme colds mean a higher number of degree days. The higher the number of degree days, the more heat is needed to warm up or cool down somewhere. In this sense, it is important to reduce the energy consumption costs and obtain the maximum benefit by managing the environmental problems related to the energy consumption correctly. The correct estimation of the future energy demand and developing adaptation strategies to changing energy demand are related to the most accurate prediction of climate change relevant heating and cooling needs. In this study, it is projected that how the heating and cooling degree days in Turkey will covary with climate change under the RCP8.5 scenario, which consists in intense greenhouse gas emissions as it is today. For this purpose, the heating and cooling
\end{abstract}


degree days calculated using the high resolution temperature values obtained from the RegCM regional climate model are compared for the future periods of 2016-2035 and 2046-2065 with respect to the reference period of 1981-2000. The climate outputs of the MPI-ESM-MR global circulation model, which is developed and run by the Max Planck Institute of Meteorology in Germany, are dynamically downscaled from approximately $139 \mathrm{~km}$ horizontal resolution to $10 \mathrm{~km}$ horizontal resolution via RegCM4.4 using double-nested technique. In the study, the base temperature for the heating degree day is taken as $18^{\circ} \mathrm{C}$ and for the cooling degree day as $24^{\circ} \mathrm{C}$. Consequently, it is found that the number of heating degree days will decrease in the whole country, whereas the number of cooling degree days will generally increase. The decrease in the number of heating degree days is much more apparent in high altitudes. The reduction in heating degree days and the rise in cooling degree days will also be higher in the period of 2046-2065 rather than in the period of 2016-2035. According to the result of the study, the utmost decrease in the heating degree days will be seen in Sivas, Kayseri, Kahramanmaraş, and Mersin for both future periods in terms of chosen provinces. For the period of 20162035, the highest increase in the cooling degree days will be occurred in Şanlıurfa, Diyarbakır, Adana, and Manisa respectively, whereas the maximum increase in the cooling degree days will be experienced in Şanlıurfa, Diyarbakır, Adana, and Hatay for the period of 2046-2065. The most remarkable point here is that Hatay is ranking as the fourth in the period of 2046-2065 instead of Manisa, which has the fourth highest increase in cooling degree days during the period of 2016-2035. In the scope of the study, four different groups are categorized as tourism region (province basis), industrial region (province basis), top 6 provinces with the highest migration and top 10 most populous provinces. The results are also analyzed for these categories. In the industrial region and the most populous provinces categories, the maximum reduction in heating degree days will be in Konya for the period of 2016-2035 and in Ankara for the period of 2046-2065. In the category of the most migration-receiving provinces, the most likely decrease in heating degree days for both future periods will be in Ankara, while the most significant decrease in heating degree days for both future periods will be in Sivas in the category of tourism region. Similarly, when the changes in cooling degree days are examined for each category, it is projected that the maximum increase in cooling degree days will occur in Manisa for both future periods in the industrial region category. In the most populous provinces and tourism region categories, the maximum increase in cooling degree days will be in Şanliurfa for both future periods. The highest increase in cooling degree days will also occur in İzmir for both future periods in the most migration-receiving category. To summarize, study results indicate that a warmer temperature normal in Turkey will be very likely experienced in the future. At this point, assessment of the projected changes in degree days are very crucial because the indicators such as heating degree days and cooling degree days are used in energy planning and they give decisive support to construction decisions as well. They also provide information to determine the mitigation strategies between climate and energy use. Hence, the measures to be taken for this aim are very critical both in terms of energy saving and the sustainability of the cities due to the buildings. In addition, this study is the first research which investigates the prospective changes in heating and cooling degree days using the highest resolution climate model outputs for Turkey.

Keywords: Heating and cooling degree days, Climate change, Climate projections for Turkey, Climate modeling.

\section{Gỉniş}

İklim değişikliği ve buna bağlı aşırı iklim olaylarının şiddeti ve yoğunluğunda yaşanması muhtemel değişimlerin gelecekteki enerji talebini etkilemesi beklenmektedir. $\mathrm{Bu}$ değişimler daha sıcak ve daha soğuk iklim koşullarına işaret etmektedir. Daha sıcak ya da daha soğuk iklim koşulları, ısınma ve soğutma ihtiyaçlarındaki değişikliği de beraberinde getirecektir.

İklim değişikliğinin kısa vadede yaratacağı etkilere tüketicilerin vereceği davranışsal tepki ve uzun vadedeki değişime göstereceği uyumun gelecekte enerji tüketimini etkilemesi beklenmektedir [1]. Daha sıcak iklim koşullarında yaşayan tüketiciler, 1sıtma ve soğutma ihtiyacında doğalgaz ya da petrol kullanımından ziyade elektrik kullanmayı tercih etmektedirler. Bir başka deyişle, daha sıcak iklimin hakim olduğu yerlerde hem kurumlar hem de haneler isitma ve soğutmada elektrik kullanmaktadırlar [2]. Bu nedenle, bu bölgelerde yaşayan tüketicilerin ısıtma ya da soğutma ihtiyacındaki artış gelecekteki enerji talebini etkileyecektir. İklim değişikliğine bağlı kış aylarında havaların aşırı soğuması ve yaz aylarında aşırı ısınması enerji tüketimini arttırmakta, bu artışa bağlı olarak hane halkı ya da kullanıcı ısınma maliyetleri de artmaktadır. Enerji maliyetlerindeki bu artıştan ne kadarının iklim kaynaklı olduğunun tespit edilebilmesi ancak gün derece hesaplamaları yardımıyla yapılabilmektedir. Gün dereceleri hesaplanırken baz sıcaklık (ASHRAE'ye [3] göre baz sıcaklıklar denge noktası sicaklıkları olarak da isimlendirilmektedir) ile dış sıcaklık karşılaştırılmaktadır. Sıcak günler soğutma gün dereceleri hesaplanırken, soğuk günler ise isıtma gün dereceleri hesaplanarak dikkate alınmaktadır. Daha fazla aşırı sıcaklık ya da aşırı soğukluk daha yüksek sayıda gün derecesi anlamına gelmektedir. Daha yüksek sayıdaki gün derecesi de bir yerin 1sıtılması ya da soğutulmasında daha fazla enerji tüketilmesi ihtiyacı doğurur. Bu anlamda enerji tüketimine bağlı çevresel sorunların doğru yönetilmesiyle enerji tüketim maliyetlerinin düşürülmesi ve maksimum faydanın elde edilmesi gelecek enerji talebi açısından önemlidir. Gelecek enerji talebinin doğru tahmin edilmesi ve karşılanabilmesi iklim değişikliği kaynaklı 1sıtma ve soğutma ihtiyacının en doğru şekilde öngörülmesiyle ilişkilidir. 
Günümüze kadar yapılan çalışmalarda, geçmişteki enerji kullanım eğilimini incelemede kullanılan $[4,5,6$, $7,8,9,10,11,12]$ en temel ve pratik yöntem olarak karşımıza çıkan ısıtma ve soğutma gün derecelerinden gelecekteki enerji talebini öngörmede de yararlanılmaktadır [13, 14, 15, 16, 17, 18]. Matzarakis ve Balafoutis [7], çalışmalarında günlük minimum ve maksimum sıcaklıkları kullanmış ve denge noktası sıcaklık değerini $14^{\circ} \mathrm{C}$ olarak dikkate almıştır. Christenson vd. [6] ise İsviçre için aylık sıcaklık verisi kullanarak iklim değişikliğine bağlı sıcaklık artışının gün derece ve binalardaki 1sıtma üzerindeki etkilerini incelemiştir. Sailor [19], enerji tüketimini iklimsel koşullara göre daha iyi temsil eden nüfusa göre ağırlıklandırılmış iklim verisi kullanarak hava sıcaklıklarındaki değişimlerin enerji tüketimi üzerindeki etkisinin gün dereceleri ile ilişkisini değerlendirmiştir. Pardo vd. [20] ve Valor vd. [21] yaptıkları çalışmalarda hava sıcaklıklarındaki değişimlerin enerji tüketimi üzerindeki etkisini incelemiş ve gün dereceleri ile doğrudan ilişkili olduğunu ifade etmişlerdir. Pardo vd. [20], İspanya'da enerji talebi ile hava koşulları arasındaki ilişkiye bakmış, 1sıtma ve soğutma gün derecelerine bağlı günlük enerji yükünü tahmin etmişlerdir. Valor vd. [21], yine İspanya'da ağırlıklı nüfus sıcaklık indeksi kullanarak enerji yükü ile günlük hava sıcaklığı arasındaki ilişkiyi incelemiş ve doğrudan etkiye dikkat çekmişlerdir. Martinaitis [22], gün derece hesaplamasına yönelik çalışmasında, 1sıtma sezonu için kümülatif hava sıcaklığı süre fonksiyonu metodu kullanmış ve bu fonksiyona 1sıtma sezonu için gerekli limit sıcaklık değerlerini ekleyerek binaların yaşam döngüsüne bağlı enerji tüketim sorunlarının çözümüne yönelik bir metot ortaya koymuştur. OrtizBeviá vd. [23] tarafından İspanya'da nüfus ağırlıklı sıcaklık indeksi baz alınarak 1sıtma ve soğutma gün derecelerinin evsel enerji talebi üzerindeki etkisine bakılmış, 1sıtma ve soğutma gün dereceleri değişimleri incelenmiştir.

Benestad [15], iklim değişikliğinin ısıtma ve soğutma gün derecelerine etkisini istatistiksel ölçek küçültme metoduyla içlerinde Adana, Ankara ve İstanbul'un da bulunduğu Avrupa'daki çeşitli şehirler için incelemiştir. IPCC'nin bir önceki senaryo setlerinden biri olan A1B senaryosuna göre yapılan analizde, Avrupa'nın genelinde 2021-2050 ve 20712100 dönemlerinde 1961-1990 referans dönemine kiyasla 1sıtma gün derece sayısında azalma ve soğutma gün derece sayısında ise bir artış eğilimi olacağı sonucuna varılmıştır.

Wang ve Chen [18], Amerika Birleşik Devletleri'nde farklı yerleşim alanlarındaki binaların enerji tüketimlerine ilişkin yaptıkları öngörüde düşük (B2), yoğun (A2) ve çok yoğun (A1FI) sera gazı salım senaryolarını dikkate almışlardır. İklim değişikliğinin enerji tüketimi üzerindeki etkisinin yapıların özelliklerine göre farklılık gösterdiği belirtilmiş ve gelecekte farklı iklim alanına göre bazı yerleşim yerlerinde (Miami, Houston, Atlanta, Baltimore vs.) kaynak enerji kullanımında net artış beklenirken, bazı yerlerde (Madison, Portland, Minneapolis) ise azalma olacağı ifade edilmiştir.

Büyükalaca vd. [5] tarafından Türkiye'deki istasyon verilerinden faydalanılarak 14 yıllık bir zaman dilimi (19811995) için farklı denge noktası sıcaklık değerlerini dikkate alarak il bazında yıllık 1sıtma ve soğutma gün derecelerini hesaplanmıştır. Bu çalışmaya göre, $24{ }^{\circ} \mathrm{C}$ 'lik denge noktası eşik olarak alındığında soğutma gün derece sayısı en yüksek il Şanlıurfa olurken (665 gün derece), bu değer Kars ve Ardahan illerinde 0 olarak tespit edilmiştir. $18^{\circ} \mathrm{C}$ 'lik denge noktası sıcaklığına göre 1sıtma gün derece sayısı en yüksek il Ardahan olurken (5137 gün derece), 1sıtma gün derece sayısı en düşük il ise İskenderun olarak belirtilmiştir (690 gün derece). Benzer bir diğer çalışmada Dombaycı [8] Türkiye'deki 79 il merkezindeki istasyonlara ait minimum ve maksimum sicaklık verilerini kullanarak farklı denge noktası sıcaklıklarına göre 1985-2005 dönemi için 1sıtma ve soğutma gün derecelerini hesaplamıştır. Örneğin; $24{ }^{\circ} \mathrm{C}$ 'lik denge noktasına göre en fazla soğutma gün derece sayısı Şanlıurfa'da görülürken (761 gün derece), en az soğutma gün derece sayısı ise Ardahan olarak bulunmuştur (12 gün derece). $17.5^{\circ} \mathrm{C}$ 'lik denge noktasina göre en fazla 1sitma gün derece sayısı Ardahan ilinde gözlemlenirken (4581 gün derece), en az 1sıtma gün derece sayısı görülen il ise Mersin olmuştur (783 gün derece). Son olarak Coşkun vd. [24] tarafından iklim değişikliğinin Türkiye'deki enerji tüketimine etkisi gelecekteki üç farklı dönem için (2016-2040, 20412070 ve 2071-2098) araştırılmıştır. Söz konusu çalışmada HadGEM2-ES küresel iklim modeli, RegCM4.3.4 bölgesel iklim modeli kullanılarak iki farklı senaryo için (RCP4.5 ve RCP8.5) 20 km'lik bir çözünürlüğe indirgenmiş ve 1sıtma gün derece ile soğutma gün derece değerlerinin hesaplanmasında buradan elde edilen ortalama sıcaklık değerleri kullanılmıştır. Coşkun vd. [24], 1sıtma gün derecelerinin hesaplanmasında 1sıtma eşik değeri olarak $15^{\circ} \mathrm{C}$ 'yi ve soğutma gün derecelerinin hesaplanmasında soğutma eşik değeri olarak $22{ }^{\circ} \mathrm{C}$ 'yi seçmişlerdir. Mevsimsel ve yıllık analiz sonuçlarına göre iklim değişikliğine bağlı olarak Türkiye'de 1sıtma gün derecelerinde azalış, soğutma gün derecelerinde ise artış olacağı öngörülmüştür. Özellikle yaz aylarındaki soğutma ihtiyacının daha fazla artacağı görüldüğünden yaz mevsiminde ülkemizde soğutma amaçlı enerji tüketiminde de bir artış beklenebileceği belirtilmiştir.

Türkiye'nin nüfusunun 2023 yilında 84.2 milyona ulaşacağı ve 2050 yılında ise en yüksek seviye olan 93.4 milyona erişeceği tahmin edilmektedir [25]. Dolayısıyla artan nüfusa bağlı olarak zaten artması öngörülen enerji talebinin iklim değişikliğiyle beraber bu artışa nasıl etkide 
bulunacağı da enerji planlamalarında dikkate alınması gerekmektedir. Bu bağlamda, iklim değişikliğinin etkilerine yönelik alansal ve zamansal değişimleri istatistiksel ve dinamik ölçek küçültme yaklaşımlarıyla öngören çalışmalar $[26,27,28,29]$ özellikle önem arz etmektedir. Tüm bu bilgiler 1şığında, bu çalışma Türkiye için bu zamana kadar elde edilen en yüksek çözünürlüklü $(10 \mathrm{~km})$ bölgesel iklim modeli verisini kullanarak yoğun sera gazı salımına devam edilmesi halinde (RCP8.5 senaryosu) yakın ve orta gelecekte (2016-2035 ve 2046-2065) 1sitma ve soğutma gün derecelerinde nasıl bir değişiklik olacağını incelemektedir. Ayrıca daha önceki çalışmalardan farklı olarak bölgesel iklim modeli RegCM'in daha güncel versiyonu (RegCM4.4) ve farklı küresel iklim modeli (MPI-ESM-MR) girdisi kullanılmıştır.

\section{VERI VE METODOLOJi}

$\mathrm{Bu}$ çalışmada iklim değişikliğine bağlı olarak gelecekteki isıtma ve soğutma gün derecelerinin hesaplanabilmesi için bölgesel iklim modelinden faydalanılmıştır. Bu bağlamda İtalya'da bulunan Abdus Salam Uluslararası Teorik Fizik Merkezi (The Abdus Salam International Centre for Theoretical Physics-ICTP-) tarafından geliştirilmiş ve adı RegCM olan bölgesel iklim modelinin 4.4 kodlu versiyonu düşük çözünürlüklü iklim verisinden daha yüksek çözünürlüklü iklim verisi elde etmede kullanılmıştır [30]. İlk olarak Almanya'daki Max Planck Meteoroloji Enstitüsü'nün geliştirip çalıştırdığı ve yaklaşık 139 km'lik yatay çözünürlüğe sahip MPIESM-MR küresel dolaşım modelinin [31] hem geçmiş hem de RCP8.5 senaryosuna göre elde edilmiş iklim çıktıları, RegCM4.4 bölgesel iklim modelinde başlangıç ve sınır koşullarını oluşturarak Türkiye ve çevresi için önce 50 km'lik yatay çözünürlüğe dinamik olarak küçültülmüş ve sonrasında buradan elde edilen çıktılar RegCM4.4 modeline başlangıç ve sınır koşulları olarak verilmek suretiyle ikinci kez model çalıştırılarak Türkiye için 10 km'lik bir yatay çözünürlüğe dinamik olarak ölçeklendirilmiştir. Modelin parametrizasyonu ve geçerlilik sınamaları Turp vd. [28] tarafından yapılan çalışmada belirtildiği şekilde gerçekleştirilmiştir. Çalışmada kullanılan RCP8.5 senaryosu [32], Hükümetlerarası İklim Değişikliği Paneli (IPCC)'nin en güncel iklim değişikliği senaryolarından biri olup, iklim değişikliği çalışmalarında genel olarak kötümser senaryoyu (literatürde business as usual olarak yer alır-BAU) temsil eder. RCP8.5 senaryosu yoğun sera gazı salımını göz önüne alarak atmosferik $\mathrm{CO}_{2}$ seviyesinin bu yüzyılın sonunda yaklaşık 936 ppm değerine ulaşacağını öngörür [33].

\section{I. Isıtma ve Soğutma Gün Derecelerinin Hesaplanması}

\section{I.I. Kavramların tanımlanması}

Binalardaki ısıtma ya da soğutma sistemlerinde ihtiyaç duyulan enerjinin hesaplanması, tüketilen enerji miktarı hava koşullarına bağlı değişiklik gösterdiği için diğer enerji tüketimlerine göre biraz daha karmaşık olmaktadır. Her bir saatlik ısıtma ya da soğutma için ne kadar enerji tüketilmesi gerektiği iklimsel koşullardan etkilenmektedir. İklim değişikliği kaynaklı sıcaklık ortalamalarındaki artış ya da aşırı sıcak ve soğuk dalgaları gibi aşırı hava olaylarının da binalardaki ısıtma ve soğutmaya bağlı enerji ihtiyacı üzerinde etkisi bulunmaktadır.

Dişarısı 1sındıkça ya da soğudukça binaların soğutulması ve 1sitılması için gerekli olan saat başına enerji tüketimi artmaktadır. Soğuk iklim koşullarında yer alan bölgelerde binaların 1sıtılması için gerekli enerji, sıcak iklim koşullarındaki bölgelere göre daha fazladır. Örneğin; Portekiz'de $100 \mathrm{~m}^{2}$ 'lik bir meskeni 1 sıtmak için yıllık $16 \mathrm{kWh} / \mathrm{m}^{2}$ 'lik enerji gerekirken, Polonya'da aynı büyüklükte bir mesken için Portekiz'dekinin 10 katı kadar $\left(160 \mathrm{kWh} / \mathrm{m}^{2}\right)$ enerjiye ihtiyaç duyulmaktadır [34]. Ayrıca gün içinde gece ile gündüz sıcaklık farkları gibi farklı saatlerde farklı sıcaklık dereceleri ortaya çımmakta, buna bağlı olarak dış sıcaklık aynı lokasyonda da zaman içinde değişiklik göstermektedir. İnsanlar dışarının sıcaklığının değişmesine bağlı binaların içindeki ısıyı ortalama bir ısıda sabit tutmaya çalışırlar. Isıtma ve soğutma gün derecesi de tüm bunları sayısal olarak hesaplamak için kullanılan basit bir yöntemdir. Dolayısıyla, herhangi bir gün, hafta, ay ya da yılda bir binanın 1sıtılması ya da soğutulması için gerekli olan enerji miktarı herhangi bir gün, hafta, ay ya da yılda 1sıtma ya da soğutma gün derece sayısıyla doğrudan orantılıdır.

$\mathrm{Bu}$ hesaplamalar yapılırken bazı tanım ve kavramların iyice anlaşılması gerekmektedir ve bu kavramlar aşağıdaki şekilde ifade edilmektedir:

Gün derecesi: Gün derecesi verisi belirli bir dönem ya da belirli bir sezonda iklimsel değişime göre, ısıtma ya da soğutma ihtiyaçlarının belirlenmesi için kullanılmaktadır. Gün dereceleri üç ayrı sınıfta kategorilendirilmektedir: 1sıtma gün derecesi, soğutma gün derecesi ve büyüme (yetişme) gün derecesi.

Gün derece hesaplamaları aşağıda yer alan zaman parametreleri kapsamında hesaplanabilmektedir [35].

- Ortalama saat dereceleri, saatlik sıcaklık gözlem değerleri

- Günlük minimum ve maksimum sıcaklıklar

- Günlük ortalama sıcaklıklar

- Aylık standart sapma ve aylık ortalama sıcaklıklardan aylık gün derece hesaplamaları 
Nüfusa göre ağırlıklandırllmıs gün derecesi: Gün derecesi verisi bir bölgedeki enerji tüketimini tahmin etmek için nüfusa göre ağırlıklandırılabilir. Bunu hesaplayabilmek için örneğin bir ülke içinde her bir bölge için gün derecesi o bölge için belirlenen nüfus ağırlığı ile çarpılmaktatır. Birçok bilimsel çalışma nüfusa göre ağırlıklandırılmış gün derecesini kullanmaktadır [36].

Denge noktası sıcaklığl (Baz sıcaklık): Denge noktası s1caklığı, kış aylarında bir yerin ısıtılması için ihtiyaç duyulan en düşük sıcaklık olarak, yaz aylarında ise bir yerin soğutulması için gerekli olan en yüksek sıcaklık olarak ifade edilmektedir.

Yaz ve kış aylarında 1sıtma ve soğutmaya bağlı gün derecelerinden yararlanılarak enerji ihtiyacı hesabı yapılırken denge noktası sıcaklığının [3] doğru belirlenmesi çok önemlidir. Isıtma ve soğutma gün derecelerinin denge noktası s1caklığından yararlanılarak nasıl hesaplandığı aşağıda örneklendirilerek açıklanmıştır.

Denge noktası slcaklığ karmașasl: Denge noktası konusundaki en büyük yanlış algı, standart bir denge sıcaklığının bulunduğu yönündedir. Ancak bu doğru olmadığı için gün dereceleri hesaplanırken denge noktası sicaklığının doğru belirlenmesi çok önemlidir. Denge noktası sıcaklıkları bir yerden bir yere değişiklik gösterebilir. Örneğin; bir ana sunucu bilgisayar alanının bulunduğu yerin yeterince serin olması gerektiğinden denge noktası sıcaklığg bir ofisinkinden farklıdır ya da kış aylarında kapalı bir havuzun bulunduğu yerdeki, bir fabrika daki ya da bir evdeki denge noktası s1caklığı birbirine göre farklılık göstermektedir. Doğal olarak bu farklılık enerji tüketimine de farklı yansımaktadır. Bu nedenle gün derecesi hesaplanırken kullanılacak olan denge noktası sıcaklığı belirlenirken alanın kullanım amacı, büyüklüğü, yapısı, içinde bulunan ekipmanlar da dikkate alınmalıdır. Bir yerin iklimsel farklılığı bize doğru denge sıcaklığını bulmamızda yardımcı olur ve bu sayede ne kadar bir enerji ihtiyacının bulunduğu öngörülebilir.

Isttma gün derecesi (IGD - heating degree days-HDD): Isıtma gün derecesi bir binanın ısıtılması için gerekli olan enerji ihtiyacının tespit edilmesi için kullanılan bir ölçümdür. $\mathrm{Bu}$ ölçümleme yapılırken dış sıcaklıktan ve denge noktası sıcaklığından yararlanılmaktadır. Bir başka deyişle ısıtma gün derecesi, dışarının sıcaklığg denge noktası sıcaklığının altına düşmesi durumunda hesaplanmaktadır [37, 38] .

Soğutma gün derecesi (SGD-cooling degree days-CDD): Soğutma gün derecesi de 1sitma gün derecesinin tam tersi şeklinde yorumlanabilir. Açıklamak gerekirse dışarının sıcaklığının belirli bir derecenin üzerinde olması durumunda (denge noktası sıcaklığı) içerinin soğutulma ihtiyacının belirlenmesi için başvurulan yöntem olarak ifade edilmektedir.
Bir başka deyişle ısıtma gün derecesinin tersine soğutma gün derecesi dışarının sıcaklığının denge noktası sıcaklığının üstüne çıkması durumunda hesaplanmaktadır [37, 38] .

\section{I.2. Gün derecesi hesaplamaları}

Isıtma gün derecesi (IGD): Kış aylarında enerji tüketimi öngörüsü hesabı yapılırken yukarıda belirtildiği üzere öncelikle doğru denge noktası sıcaklığı belirlenmektedir. Denge noktası sıcaklığı belirlendikten sonra, bu sıcaklıktan ölçülmüş olan dış sıcaklık çıkartılarak ısıtma gün derecesi bulunmaktadir.

$I G D=\left(T_{\text {baz(dengenoktası sicaklı̆̆l })}-T_{\text {dış }}\right) *$ Gün sayısı (1)

Temel olarak 1sıtma gün derecesi hesaplanırken denge noktası sıcaklığı ile başlamak gerekir. Bir bina için denge noktası sıcaklığı, binanın 1sıtılmaya ihtiyaç duyması için gerekli olan bina sıcaklığıdır. Yani bina bu sıcaklıkta ise artık 1sıtılmaya ihtiyacı var demektir. Bu sürecin nasıl işlediğini anlamak enerji tüketimini iyi yönetmek açısından gerçekten önemlidir. Bu çalışmada IGD denge noktası sıcaklığı $18^{\circ} \mathrm{C}$ olarak alınmıştır.

Isıtma gün derecesinin en doğru ve en uygun şekilde hesaplanabilmesi için, her bir zaman diliminde (saatlik, günlük vs.) dış sıcaklığın sabit olduğu varsayılarak sıcaklığın sabit olduğu gün sayısı ile denge noktası sıcaklığının altında kalan sıcaklık farkı çarpılmakta ve istenilen gün sayısı bazında 1sıtma gün dereceleri toplanmaktadır. Ancak gerçek dünyada dış sıcaklık gün içinde sabit olmadığından yani zaman içinde çok fazla değişiklik gösterdiğinden, doğru bir hesaplama için sınırsız sayıda sıcaklık değerine ihtiyaç duyulmaktadır. Bir başka deyişle gerçeğe en yakın 1sıtma gün derecesi hesabı için gün içinde mümkün olduğunca fazla sayıda sıcaklık değeri verisi kulanılması gerekmektedir (Mümkünse yarım saatlik veri bile olabilir, ancak bu veri istasyon verisinden değil de model çıktılarından elde edilecekse çok fazla saklama kapasitesi gerektirdiğinden bu kadar fazla sıcaklık verisine ulaşmak çok kolay olmamaktadır, bu nedenle günlük ortalama, minimum ve maksimum sicaklıklar kullanılmaktadır.) [39].

Soğutma gün derecesi (SGD): Yaz aylarında enerji tüketimi öngörüsü hesabı yapılırken yine öncelikle doğru denge noktasının belirlenmesi gerekir. Denge noktası sıcaklığı üzerindeki sıcaklıklar dikkate alınarak hesaplanır.

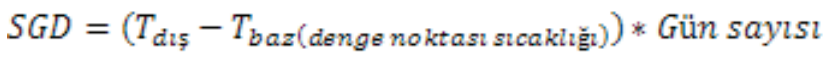

Isıtma gün derecesi için yapılan hesaplama örneklerinden soğutma gün derecesi hesaplamasında da yararlanılabilir. 
Soğutma gün derecesi ile dış sıcaklık arasında 1sıtma gün derecesinin aksine pozitif bir ilişki vardır. Bir başka deyişle dış sıcaklık arttıkça soğutma gün derecsi de artmaktadır, yani binaların soğutulması için daha fazla enerjiye ihtiyaç duyulmaktadır. Soğutma gün derecesi de Eşitlik (2)'de yeraldığı şekilde 1sıtma gün derecsi ile aynı yöntemle hesaplanmaktadır. Hesaplamadaki tek fark; 1sıtma gün derecesinde denge noktası sıcaklığından dış sıcaklık çıkarılmakta, soğutma gün derecesinde ise tam tersi işlem yapılmaktadır. Bu çalışmada SGD denge noktası sıcaklığ $24{ }^{\circ} \mathrm{C}$ olarak alınmıştır.

Yine aylık ve yıllık hesaplama ihtiyacinda, veri ihtiyacına göre elimizdeki günlük soğutma gün derecelerinden yararlanılarak aylık ya da yıllık olarak toplama işlemi yapılması gerekmektedir. Özetlemek gerekirse 1sitma gün derecesi dışarının sıcaklığı denge noktası sıcaklığının altına düştüğünde, soğutma gün derecesi ise dışarının sıcaklığının denge noktası sıcaklığının üstüne çıkması durumunda hesaplanmaktadir.

\section{BULGULAR}

\section{I. Türkiye Genelinde Gün Derece Bulguları}

Bu kısımda Türkiye'nin tamamı için yakın (2016-2035) ve orta (2046-2065) vadede isitma ve soğutma gün derecelerinin 1981-2000 referans dönemine göre nasıl değişiklik göstereceği haritalandırılarak gösterilmiştir. Haritalandırmada, mevcut koşulların (business as-usual) aynen devam ettiğini varsaydığımızda gelecekte istıma ve soğutma gün dereceleri açısından hangi dönemde hangi bölgelerde ne tür değişiklikler öngörüldüğü resmedilmiştir. Ayrıca noktasal değerler üzerinden en fazla ve en az azalmanın görüldüğü yerler belirtilmiş̧ir.

\section{I.I. Türkiye genelinde Isıtma gün derecesi bulguları}

İlk olarak Türkiye'nin genelinde RCP8.5 senaryosuna göre 2016-2035 döneminde 1981-2000 dönemine kiyasla 1sıtma gün derecelerinde y1llık ortalama kaç gün derecelik artma ya da azalma olacağ

Şekil 1'de de açikça görüldüğü üzere, Türkiye'de 20162035 döneminde ülkenin tamamında 1sıtma gün derecelerinde azalma beklenmektedir. Bu azalmanın doğu, kuzeydoğu ve güneydoğu bölgelerine gidildikçe daha fazla olacağı, ancak Ege, Akdeniz ve Karadeniz kıyıları ile Suriye sınırına yakın yerlerde daha az olacağ 1 tahmin edilmektedir. Bu dönemde ülke genelinde noktasal sonuçlara bakıldığında en fazla azalmanın Erzurum'da (-474.30 gün derece/yıl) olacağı, en düşük azalmanın ise Adana'da (-79.94 gün derece/yıl) olacağı öngörülmektedir. Bahadır [12] tarafından da belirtildiği üzere, ülkemizde yükselti ve karasallık sıcaklığın dağılışında etkili faktörler olduğundan iç kesimlere ve doğuya gidildikçe 1sıtma gün dereceleri artar. Ancak, iklim değişikliği ile beraber yükseltinin fazla olduğu yerlerde sıcaklık artışı ile birlikte bu bölgelerde 1sıtma gün derecelerinde azalış daha çarpıcı olacaktır.

Benzer şekilde, 2016-2035 dönemi için öngörülen azalmanın 2046-2065 dönemine gelindiğinde çok daha fazla olacağ1 Şekil 2'de gösterilmektedir. 2046-2065 döneminde beklenen azalmanın özellikle ülkenin kuzeydoğusunda 2016-2035 döneminde beklenen azalmanın 2-2.5 katı kadar olacağı sonucuna varılmaktadır. Bu dönemde noktasal sonuçlara göre 1sıtma gün derece sayısında en fazla azalma Hakkari'de (-1041.50 gün derece/yıl) beklenirken, en az değişimin Hatay'da (-238.49 gün derece/yıl) olacağ1 öngörülmektedir.

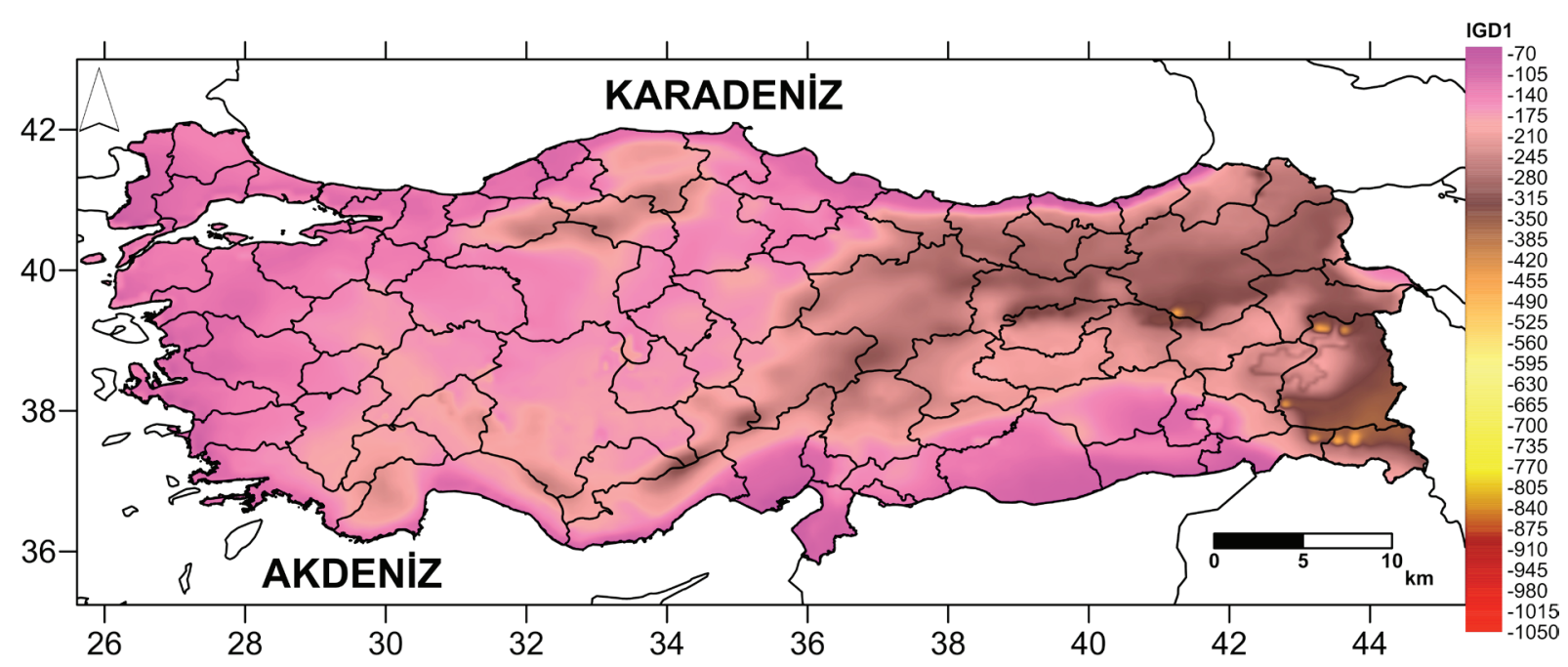

Şekil 1. Isıtma gün derecelerinin gelecek 2016-2035 döneminde 1981-2000 referans dönemine göre değişimi (gün derece/y1l) 


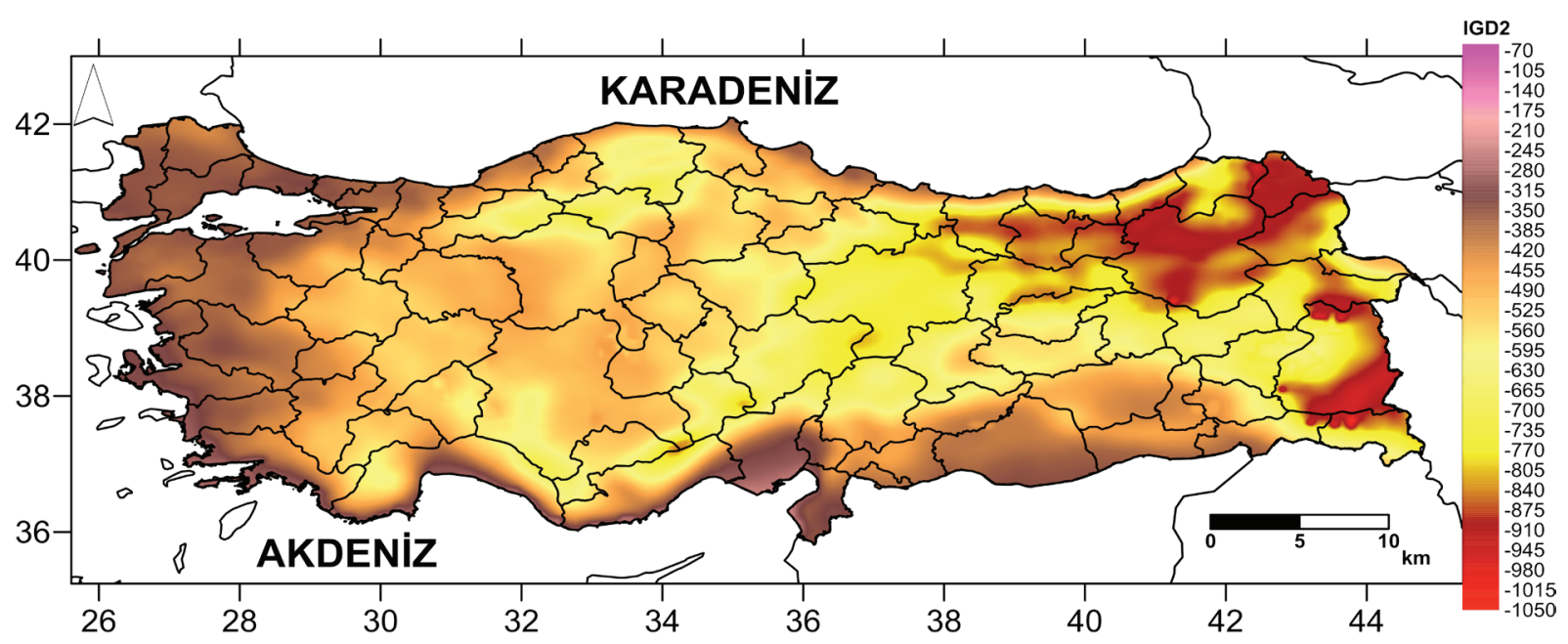

Şekil 2. Isıtma gün derecelerinin gelecek 2046-2065 döneminde 1981-2000 referans dönemine göre değişimi (gün derece/yıl)

\subsubsection{Türkiye genelinde soğutma gün derecesi bulguları}

Türkiye'de 1sitma gün derecelerinde gelecekte beklenen değişimin ardından, soğutma gün derecelerinde öngörülen değişikliğe göz atılacak olursa, 1sıtma gün derecelerinde beklenen azalma eğiliminin tersine bir artış eğilimi ile karşılaşılmaktadır. Şekil-3'te de görüldüğü gibi, RCP8.5 senaryosuna göre Türkiye'nin genelinde 2016-2035 dönemindeki soğutma gün derece sayılarında 1981-2000 referans dönemine oranla bir artma olacağı öngörülmektedir. Bu dönemde tahmin edilen artışın özellikle Güneydoğu Anadolu, Batı ve Güneybatı Anadolu bölgeleri ile Akdeniz kıyısı boyunca daha fazla olacağ1 görülmektedir. Noktasal sonuçlara göre 2016-2035 döneminde en fazla artışın Şanlıurfa'da (185.07 gün derece/ yıl) görülmesi beklenirken, bazı yerlerde azalma da görülebilecektir. Mesela; Sakarya ilinde çok az miktarda da olsa bir azalma (-0.96 gün derece/yıl) olacağı öngörülmektedir.

Soğutma gün derece sayllarında beklenen değişikliklere 2046-2065 dönemi için bakıldığında ise ülkenin genelinde 1981-2000 referans dönemine nispeten yine bir artıs olacağı öngörülmüş olup, bu artışın 2016-2035 dönemine göre çok daha fazla olacağı dikkat çekmektedir (Şekil-4). Çoğu yerde geçmiş referans döneme nazaran soğutma gün derecelerinde çok dikkat çekici bir değişim beklenmezken, noktasal sonuçlara göre bu sefer Şanlıurfa ilinde beklenen artışın yıllık ortalama 506.96 gün derece olacağı beklenmektedir. Ayrıca 2046-2065 döneminde 2016-2035 döneminden farklı olarak İç Anadolu Bölgesi'ndeki dağılımdaki değişiklik de dikkat çekicidir.

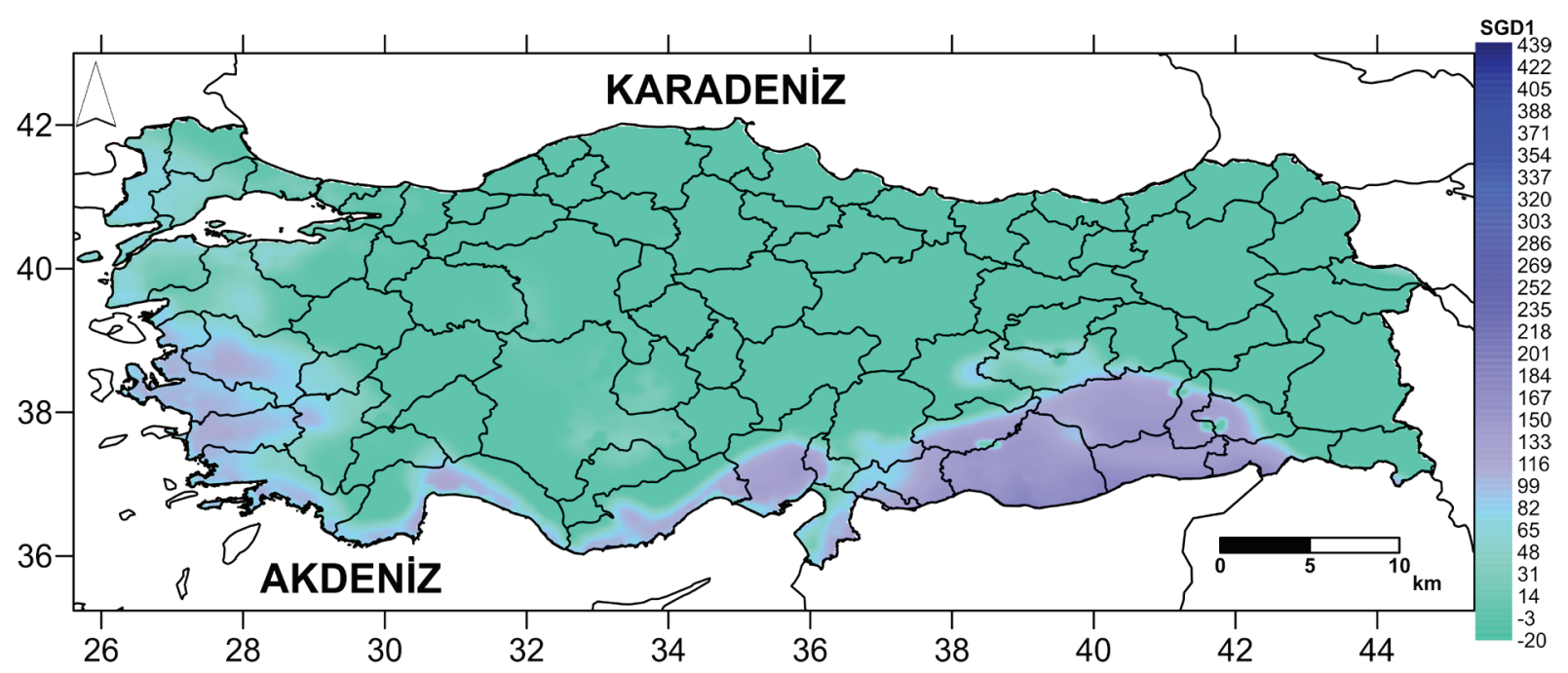

Şekil 3. Soğutma gün derecelerinin gelecek 2016-2035 döneminde 1981-2000 referans dönemine göre değişimi (gün derece/yıl) 


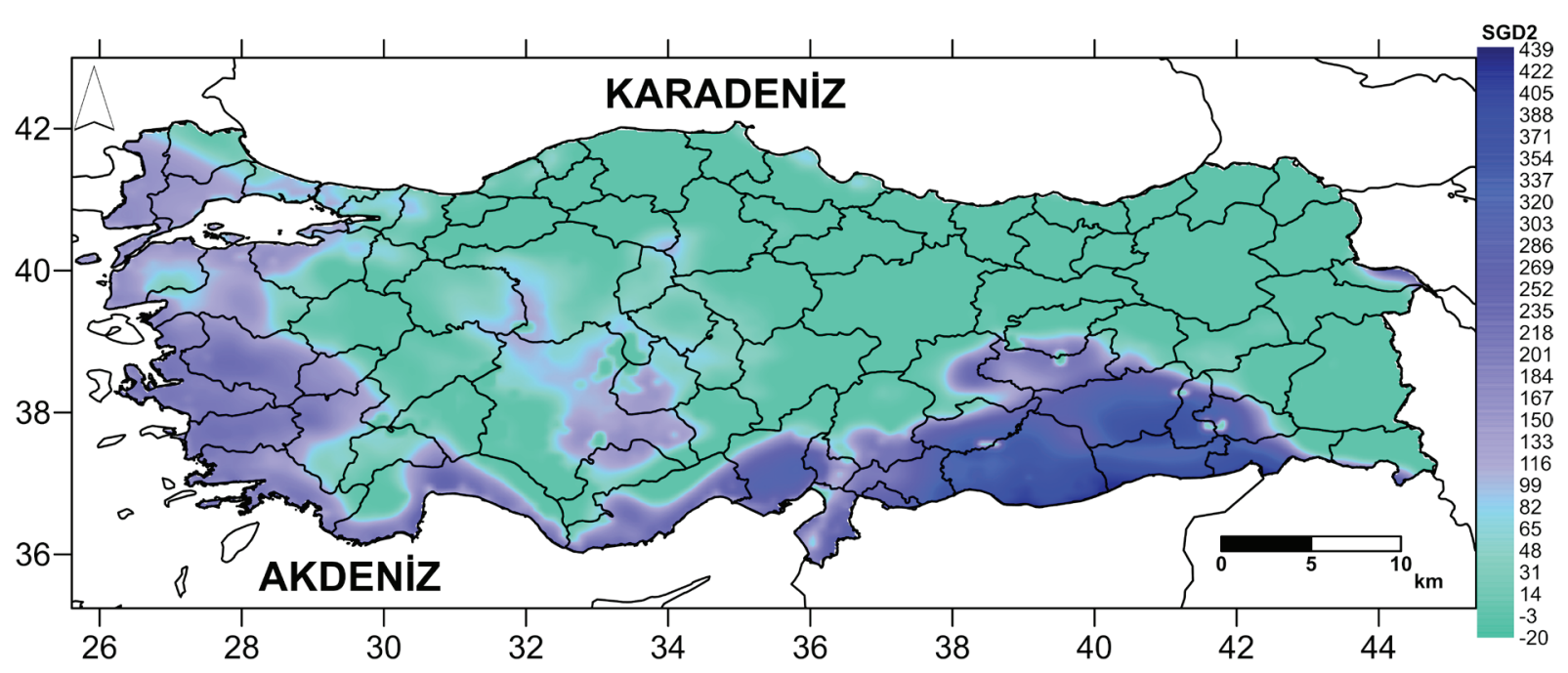

Şekil 4. Soğutma gün derecelerinin gelecek 2046-2065 döneminde 1981-2000 referans dönemine göre değişimi (gün derece/y1l)

\subsection{Türkiye Bölgelere Göre Gün Derecesi Bulguları}

Bölgelere göre gün derecesi analizi, Türkiye genelinde bölgesel kategorilendirme yapılarak gerçekleştirilmiştir. Çalışma kapsamında 4 ayrı çalışma bölgesi belirlenmiş olup kategorilendirilen bölgeler; turizm bölgesi (il bazında), sanayi bölgesi (il bazında), en çok göç alan 6 il ve en kalabalık 10 il olarak değerlendirilmiştir. Buna bağlı olarak illerin merkez koordinatları dikkate alınarak ısıtma ve soğutma gün dereceleri hesaplanmıştır.

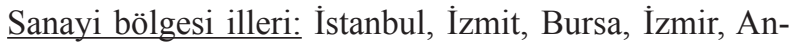
kara, Manisa, Konya, Eskişehir, Aydın, Gaziantep.

En kalabalık iller (2015): İstanbul (\%18.7), Ankara (\%6.7), İzmir (\%5.2), Bursa (\%3.6), Antalya (\%2.9), Adana $(\% 2.8)$, Konya (\%2.7), Gaziantep (\%2.4), Şanlıurfa (\%2.4), Kocaeli (\%2.2) [40].

En çok göç alan iller (1980-2015): İstanbul, Ankara, İzmir, Antalya, Kocaeli, Bursa [40].

Turizm bölgesi kategorisi belirlenirken ayrıca üç ayrı alt kategorilendirme yapılmıştır. Bu kategoriler; en fazla yatak kapasitesine göre, planlanan yatak sayısına göre ve kültürel mirasın yer aldığı illere göre belirlenmiştir. Bu kategorilerde yer alan iller birleştirilerek çalışma kapsamına dahil edilmiştir.

Turizm Bölgesi İlleri: İstanbul, Çanakkale, Balıkesir, Bursa, Manisa, Kütahya, İzmir, Afyon, Aydın, Denizli, Muğla, Antalya, Konya, Ankara, Eskişehir, Mersin, Adana, Hatay, Kayseri, Sivas, Maraş, Gaziantep, Şanlıurfa, Diyarbakır [41, 42].

Bölgesel kategorilendirmeye göre il bazında hesaplanan ısıtma gün dereceleri aşağıda sırasıyla kategorisel tablolarda verilmektedir. Kategorisel tablolarda il bazında 1981-2000 referans dönemine göre 2016-2035 ve 2046-2065 gelecek periyotlarındaki ısıtma gün derecesindeki değişim verilmektedir.

\subsection{Seçilen iller kategorisine göre ısıtma gün derecesi bulguları}

İller kategorilendirilirken, sanayi illeri, kalabalık nüfus illeri, göç illeri ve turizm illeri kapsamında genel bir değerlendirme yapılmış ve bu illerin kategori anlamında temsil ettikleri bölge bazında enerji ihtiyacının belirlenebilmesi için bir ön çalışma olarak 1sıtma gün dereceleri ve soğutma gün dereceleri hesaplanmıştır. Analiz sonuçları tablo bazında sunulmakta ve değerlendirilmektedir.

Sanayi bölgesi illerinde 2016-2035 gelecek periyodu için 1sitma gün derecelerinde en fazla azalma 180 gün derece ile Konya ilinde gözlenmekte, bunu 150 gün derece ile Ankara, 148 gün derece ile Eskişehir ili izlemektedir. Diğer 7 ilde de yine azalma görülmekte ve azalma değerleri Tablo 1'de verilmektedir. İl bazında tabloda verilen bu değerler bu dönem periyodunda dış sıcaklık ortalamalarında artış anlamına gelmekte ve binalarda ya da işyerlerinde isıtma ihtiyacında düşüş öngörülmektedir. Aynı şekilde 2046-2065 gelecek periyodunda sanayi bölgesi olarak seçilen 10 ilin tamamında 1sıtma gün derecelerinde azalma izlenmekte, bu azalma da birinci sıray 508 gün derece ile Ankara ili almakta, Konya 504 ve Eskişehir 483 gün derecesi ile onu takip etmektedir. 2046-2065 periyodunda diğer bir dikkat çeken nokta azalma rakamlarının 2016-2035 periyoduna göre 2.5-3 kat daha fazla olmasıdır ki bu da sıcaklık ortalamalarında ciddi bir artış anlamına gelmektedir. Burada yine özellikle belirtilmesi 
gereken, dış sıcaklık değeri arttıkça 1sıtma gün derecesinin azalmasıdır. Yani bir başka deyişle hava sıcaklık ortalamalarındaki artışa bağlı olarak enerji ihtiyacı azalmaktadır.

Tablo I. 1981-2000 referans dönemine göre 2016-2035 ve 20462065 dönemleri sanayi bölgesi illeri için öngörülen IGD değişim

\begin{tabular}{|l|l|l|}
\multicolumn{3}{|c|}{ değerleri } \\
\hline Sanayi Bölgesi İlleri & $\mathbf{2 0 1 6 - 2 0 3 5}$ & $\mathbf{2 0 4 6 - 2 0 6 5}$ \\
\hline İL & -135.08 & -418.87 \\
\hline İstanbul & -138.69 & -376.04 \\
\hline İzmit (Kocaeli) & -137.64 & -455.89 \\
\hline Bursa & -117.52 & -363.98 \\
\hline İzmir & -150.59 & -508.49 \\
\hline Ankara & -128.57 & -352.59 \\
\hline Manisa & -180.65 & -504.32 \\
\hline Konya & -148.26 & -483.40 \\
\hline Eskişehir & -134.73 & -367.80 \\
\hline Aydın & -164.61 & -449.69 \\
\hline Gaziantep & &
\end{tabular}

En kalabalık nüfuslu 10 ilde 2016-2035 gelecek periyodu için 1sıtma gün derecelerinde en fazla azalma 180 gün derece ile yine Konya ilinde gözlenmekte, bunu 164 gün derece ile Gaziantep 150 gün derece ile Ankara ili izlemektedir. Diğer 7 ilde de yine aynı şekilde azalma görülmekte ve azalma değerleri Tablo 2'de verilmektedir. Aynı şekilde 2046-2065 gelecek periyodunda en kalabalık nüfuslu iller kategorisinde 10 ilin tamaminda isitma gün derecelerinde azalma izlenmekte, bu azalmada birinci sırayı 508 gün derece ile Ankara ili almakta, Konya 504 ve Gaziantep 449 gün derecesi ile onu takip etmektedir. 2046-2065 periyodunda yine sanayi bölge illerinde olduğu gibi, azalma rakamları 2016-2035 periyoduna göre 2.5-3 kat daha fazladır ve bu sicaklık ortalamalarında kayda değer bir artış anlamına gelmektedir.

Tablo 2. 1981-2000 referans dönemine göre 2016-2035 ve 20462065 dönemleri en kalabalık nüfuslu iller için öngörülen IGD değişism değerleri

\begin{tabular}{|l|l|l|}
\hline \multicolumn{3}{|l|}{ En Kalabalık Nüfuslu İler } \\
\hline İL & $\mathbf{2 0 1 6 - 2 0 3 5}$ & $\mathbf{2 0 4 6 - 2 0 6 5}$ \\
\hline İstanbul & -135.08 & -418.87 \\
\hline Ankara & -150.59 & -508.49 \\
\hline İzmir & -117.52 & -363.98 \\
\hline Bursa & -137.64 & -455.89 \\
\hline Antalya & -121.00 & -288.21 \\
\hline Adana & -111.43 & -334.23 \\
\hline Konya & -180.65 & -504.32 \\
\hline Gaziantep & -164.61 & -449.69 \\
\hline Şanliurfa & -111.22 & -363.96 \\
\hline İzmit (Kocaeli) & -138.69 & -376.04 \\
\hline
\end{tabular}

En çok göç alan 6 ilde Tablo 3'te görüldüğü gibi 20162035 gelecek periyodu için 1sıtma gün derecelerinde en fazla azalma 150 gün derece ile yine Ankara ilinde gözlenmekte, bunu sırasıyla 138 gün derece ile İzmit, 137 gün derece ile Bursa, 135 gün derece ile İstanbul, 121 gün derece ile Antalya ve 117 gün derece ile İzmir ili izlemektedir. Aynı şekilde 2046-2065 gelecek periyodunda en çok göç alan 6 ilin tamamında 1sitma gün derecelerinde azalma izlenmekte, bu azalmada birinci sırayı 508 gün derece ile Ankara ili almakta, bunu sırasıyla 455 gün derece ile Bursa, 418 gün derece ile İstanbul, 376 gün derece ile İzmit, 363 gün derece ile İzmir, 288 gün derece ile Antalya takip etmektedir. İlk periyotta sıralama Ankara, İzmit, Bursa, İstanbul, Antalya ve İzmir iken, ikinci gelecek periyodunda bu siralama Ankara, Bursa, İstanbul, İzmit, İzmir ve Antalya olarak değişmektedir. İki gelecek dönemi arasında Antalya ve İzmir s1ralamada yer değiştirirken, aralarındaki 75 gün derece fark1 20 yıllık bir periyot için çok önemli bir fark gibi gözükmese de İzmir'in Antalya'ya göre ortalamada daha fazla 1sınacağ 1 anlamına gelmektedir. 2046-2065 periyodunda yine hem sanayi bölgesi illerinde hem de en çok nüfuslu 10 ilde olduğu gibi, azalma rakamları 2016-2035 periyoduna göre 2.5-3 kat daha fazladır ve daha fazla isınma anlamına gelmektedir.

Tablo 3. 1981-2000 referans dönemine göre 2016-2035 ve 20462065 dönemleri en çok göç alan iller için öngörülen IGD değişim değerleri

\begin{tabular}{|c|c|c|}
\hline \multicolumn{3}{|c|}{ En çok Göç Alan İller } \\
\hline İL & 2016-2035 & $2046-2065$ \\
\hline İstanbul & -135.08 & -418.87 \\
\hline Ankara & -150.59 & -508.49 \\
\hline İzmir & -117.52 & -363.98 \\
\hline Antalya & -121.00 & -288.21 \\
\hline Bursa & -137.64 & -455.89 \\
\hline İzmit (Kocaeli) & -138.69 & -376.04 \\
\hline
\end{tabular}

Turizm bölgesi illeri iki ayrı gelecek periyodu için IGD değerleri Tablo 4'te verilmiştir. Turizm Bölgesi illeri kapsamında 2016-2035 gelecek periyodunda gün derece say1sında en fazla azalma görülen iller sirasıyla Sivas, Kayseri; Kahramanmaraş, Mersin, Konya, Kütahya, Gaziantep illeri olarak; 2046-2065 gelecek periyodunda ise Sivas, Kayseri; Kahramanmaraş, Mersin, Ankara, Konya, Eskişehir olarak izlenmektedir. Bu kategoride 2016-2035 ve 2046-2065 gelecek periyotları için il bazında farklı sıralamalar olmakla birlikte bazı illerin 2016-2035 periyoduna göre ortalamada daha fazla isınacağ 1 ve daha az enerji ihtiyacı olacağ 1 söylenebilir. Ancak turizm açısından bakıldığında özellikle 2046-2065 gelecek dönemi için öngörülen gün derece sayılarındaki azalışa sebep olan ortalama sıcaklıklardaki artış, bir yandan enerji ihtiyacını azaltırken diğer yandan kültürel 
mirasın yer aldığı illeri turizm açısından zarara uğratabilir görünmektedir.

Tablo 4. 1981-2000 referans dönemine göre 2016-2035 ve 20462065 dönemleri alt kategorilere ayrılmış turizm bölgesi illeri için öngörülen IGD değerleri

\begin{tabular}{|l|l|l|}
\hline \multicolumn{2}{|l|}{ Turizm Bölgesi İlleri } & \multicolumn{2}{l}{} \\
\hline İL & $\mathbf{2 0 1 6 - 2 0 3 5}$ & $\mathbf{2 0 4 6 - 2 0 6 5}$ \\
\hline Adana & -111.43 & -334.23 \\
\hline Afyon & -146.08 & -414.80 \\
\hline Ankara & -150.59 & -508.49 \\
\hline Antalya & -121.00 & -288.21 \\
\hline Aydın & -134.73 & -367.80 \\
\hline Balıkesir & -131.60 & -375.70 \\
\hline Bursa & -137.64 & -455.89 \\
\hline Çanakkale & -130.25 & -389.30 \\
\hline Denizli & -146.91 & -395.31 \\
\hline Diyarbakır & -132.68 & -427.97 \\
\hline Eskişehir & -148.26 & -483.40 \\
\hline Gaziantep & -164.61 & -449.69 \\
\hline Hatay & -100.81 & -335.66 \\
\hline İstanbul & -135.08 & -418.87 \\
\hline İzmir & -117.52 & -363.98 \\
\hline Kahramanmaraş & -203.43 & -595.53 \\
\hline Kayseri & -218.73 & -663.16 \\
\hline Konya & -180.65 & -504.32 \\
\hline Kütahya & -172.79 & -521.69 \\
\hline Manisa & -128.57 & -352.59 \\
\hline Mersin & -199.19 & -513.16 \\
\hline Muğla & -135.45 & -333.85 \\
\hline Sivas & -270.78 & -725.99 \\
\hline Şanlıurfa & -111.22 & -363.96 \\
\hline & & \\
\hline & & \multicolumn{1}{l}{ (1) } \\
\hline
\end{tabular}

\subsubsection{Seçilen iller kategorisine göre soğutma gün derecesi analizi}

Sanayi bölgesi illerinde 2016-2035 gelecek periyodu için soğutma gün derecelerinde en fazla artı̧s 105 gün derece ile Manisa ilinde gözlenmekte, bunu 95 gün derece ile Aydın, 93 gün derece ile İzmir ili, 85 gün derece ile Gaziantep ili izlemektedir. Diğer 6 ilde gözlenen artışlar oldukça düşük seviyelerdedir. İzmit, Bursa, Ankara, Eskişehir illerindeki artı̧̧ bir anlam ifade etmemektedir. İstanbul 8 gün derecelik bir artış göstermekte ancak bu artış 20 yıllık bir periyot için anlamlı olarak değerlendirilmemektedir. İl bazında Tablo 5'te verilen bu değerler bu dönem periyodunda diş s1caklık ortalamalarında artış anlamına gelmekte ve buna dayanarak binalarda ya da işyerlerinde soğutmaya bağlı enerji ihtiyacında artış öngörülmektedir. Aynı şekilde 2046-2065 gelecek periyodunda sanayi bölgesi olarak seçilen 10 ilin tamamında soğutma gün derecelerinde artış izlenmekte, bu artışta birinci sırayı 220 gün derece ile Manisa ili, ikinci s1ray1 213 gün derece ile Gaziantep ili almakta, Aydın 198 ve İzmir 192 gün derecesi ile sırasıly üçüncü ve dördüncü s1rada yer almaktadırlar. Diğer 6 il için düşük ancak anlamlı sayılabilecek düzeyde artışlar gözlenmektedir. 2046-2065 periyodu 2016-2035 periyoduna göre soğutma gün derecesi seviyelerinde daha anlamlı düzeydedir. Burada yine özellikle dikkat edilmesi gereken, dış sıcaklık değeri arttıkça soğutma gün derecesinin artmasıdır. Yani bir başka deyişle ortalama dış sıcaklıklardaki artışa bağlı olarak enerji ihtiyacı da artmaktadır.

Tablo 5. 1981-2000 referans dönemine göre 2016-2035 ve 20462065 dönemleri sanayi bölgesi illeri için öngörülen SGD değişim değerleri

\begin{tabular}{|l|l|l|}
\hline \multicolumn{2}{|l|}{ Sanayi Bölgesi İlleri } \\
\hline İL & $\mathbf{2 0 1 6 - 2 0 3 5}$ & $\mathbf{2 0 4 6 - 2 0 6 5}$ \\
\hline İstanbul & 8.23 & 72.95 \\
\hline İzmit (Kocaeli) & 1.10 & 31.18 \\
\hline Bursa & 0.50 & 16.16 \\
\hline İzmir & 93.62 & 192.47 \\
\hline Ankara & 0.03 & 34.03 \\
\hline Manisa & 105.34 & 220.51 \\
\hline Konya & 15.03 & 117.97 \\
\hline Eskişehir & 0.52 & 36.56 \\
\hline Aydın & 95.76 & 198.52 \\
\hline Gaziantep & 85.45 & 213.14 \\
\hline
\end{tabular}

En kalabalık nüfuslu 10 ilde 2016-2035 gelecek periyodu için soğutma gün derecelerinde en fazla artış Tablo 6'da görüldüğü üzere 160 gün derece ile Şanlıurfa ilinde gözlenmekte, bunu 120 gün derece ile Adana ili izlemektedir. İzmir 93 gün derece ile, Gaziantep 85 gün derece ile ve Antalya 54 gün derece ile onları takip etmektedir. Ancak geri kalan 5 ilde Konya, İstanbul, Ankara, İzmit, Bursa ve Ankara'da gözlenen artışlar anlamlı sayılabilecek düzeyde değildir. 2046-2065 gelecek periyodunda en kalabalık nüfuslu iller kategorisinde 10 ilin tamamında soğutma gün derecelerinde artış izlenmekte, bu artışta da birinci sırayı 378 gün derece ile Şanlıurfa ili almaktadır. Bu artış 20 yıllık bir periyot için oldukça anlamlı olarak değerlendirilmektedir. Şanlıurfa ilini 273 gün derece ile Adana, 213 derece gün ile Gaziantep ve 192 gün derece ile İzmir, 139 gün derece ile Antalya, 117 gün derece ile Konya ili takip etmektedir. Diğer 4 ilde yine belirli bir seviyede artış gözlenmekte ancak düşük seviyede anlam ifade ettiği düşünülmektedir. 20462065 periyodunda yine sanayi bölge illerinde olduğu gibi, artış rakamları 2016-2035 periyoduna göre çok daha anlamlı düzeydedir. 
Tablo 6. 1981-2000 referans dönemine göre 2016-2035 ve 20462065 dönemleri en kalabalık nüfuslu iller için öngörülen SGD değişim değerleri

\begin{tabular}{|l|l|l|}
\hline \multicolumn{3}{|l|}{ En Kalabalık Nüfuslu İller } \\
\hline İL & $\mathbf{2 0 1 6 - 2 0 3 5}$ & $\mathbf{2 0 4 6 - 2 0 6 5}$ \\
\hline İstanbul & 8.23 & 72.95 \\
\hline Ankara & 0.03 & 34.03 \\
\hline İzmir & 93.62 & 192.47 \\
\hline Bursa & 0.50 & 16.16 \\
\hline Antalya & 54.99 & 139.53 \\
\hline Adana & 120.96 & 273.24 \\
\hline Konya & 15.03 & 117.97 \\
\hline Gaziantep & 85.45 & 213.14 \\
\hline Şanlıurfa & 160.84 & 378.47 \\
\hline İzmit (Kocaeli) & 1.10 & 31.18 \\
\hline
\end{tabular}

En çok göç alan 6 ilde Tablo 7'te görüldüğü gibi 20162035 gelecek periyodu için soğutma gün derecelerinde en fazla artış 93 gün derece ile İzmir ilinde gözlenmekte, bunu 54 gün derece ile Antalya ili izlemektedir. Diğer 4 ildeki artış anlamlı düzeyde değildir. Aynı şekilde 2046-2065 gelecek periyodunda en çok göç alan 6 ilin tamamında soğutma gün derecelerinde artış izlenmekte, bu artışta birinci sırayı 192 gün derece ile İzmir ili almakta, bunu 139 gün derece ile Antalya ili, 72 gün derece ile İstanbul ili izlemektedir. Diğer 3 ildeki artış seviyesi düşük seviyede anlamlı olarak nitelendirilmektedir. Ancak genel olarak artış seviyeleri bazı iller için düşük anlam ifade ediyor olsa da bu durum ortalama dış sıcaklıklarda her il için artış gözleneceği anlamına gelmektedir.

Tablo 7. 1981-2000 referans dönemine göre 2016-2035 ve 20462065 dönemleri en çok göç alan iller için öngörülen SGD değişim değerleri

\begin{tabular}{|l|l|l|}
\hline \multicolumn{2}{|l|}{ En çok Göç Alan İller } \\
\hline İL & $\mathbf{2 0 1 6 - 2 0 3 5}$ & $\mathbf{2 0 4 6 - 2 0 6 5}$ \\
\hline İstanbul & 8.23 & 72.95 \\
\hline Ankara & 0.03 & 34.03 \\
\hline İzmir & 93.62 & 192.47 \\
\hline Antalya & 54.99 & 139.53 \\
\hline Bursa & 0.50 & 16.16 \\
\hline İzmit (Kocaeli) & 1.10 & 31.18 \\
\hline
\end{tabular}

Tablo 8'e bakıldığında Turizm Bölgesi illeri kapsamında 2016-2035 gelecek periyodunda gün derece sayısında en fazla artış görülen iller sırasıyla Şanlıurfa, Diyarbakır, Adana, Manisa, Hatay, Aydın, İzmir illeri olarak; 2046-2065 gelecek periyodunda ise Şanlıurfa, Diyarbakır, Adana, Hatay, Manisa, Gaziantep, Aydın, Denizli illeri olarak izlenmektedir. Bu kategori için de 2016-2035 ve 2046-2065 gelecek periyotları için il bazında farklı sıralamalar olmakla birlikte bazı illerin 2016-2035 periyoduna göre ortalamada daha fazla 1sınacağ 1 ve daha fazla enerji ihtiyacı olacağ söylenebilir. Ancak turizm açısından bakıldığında özellikle 2046-2065 gelecek dönemi için öngörülen gün derece say1larındaki artışa sebep olan ortalama dış sıcaklıklardaki artış, bir yandan enerji ihtiyacını arttırırken diğer yandan bu kategoride özellikle soğutma gün derece sıralamalarında en üstlerde yer alan illeri turizm açısından olumsuz etkileyebilir görünmektedir. Çünkü bu illerdeki artış düzeyleri yüksek anlamlılık seviyesindedir.

Tablo 8. 1981-2000 referans dönemine göre 2016-2035 ve 20462065 dönemleri alt kategorilere ayrılmış turizm bölgesi illeri için öngörülen SGD değerleri

\begin{tabular}{|c|c|c|}
\hline \multicolumn{3}{|c|}{ Turizm Bölgesi İlleri } \\
\hline İL & 2016-2035 & 2046-2065 \\
\hline Adana & 120.96 & 273.24 \\
\hline Afyon & 67.16 & 168.97 \\
\hline Ankara & 0.03 & 34.03 \\
\hline Antalya & 54.99 & 139.53 \\
\hline Aydın & 95.76 & 198.52 \\
\hline Balıkesir & 22.03 & 96.67 \\
\hline Bursa & 0.50 & 16.16 \\
\hline Çanakkale & 15.84 & 60.99 \\
\hline Denizli & 90.47 & 197.84 \\
\hline Diyarbakır & 141.66 & 348.79 \\
\hline Eskişehir & 0.52 & 36.56 \\
\hline Gaziantep & 85.45 & 213.14 \\
\hline Hatay & 94.51 & 222.89 \\
\hline İstanbul & 8.23 & 72.95 \\
\hline İzmir & 93.62 & 192.47 \\
\hline Kahramanmaraş & 0.23 & 41.24 \\
\hline Kayseri & 0.00 & 0.00 \\
\hline Konya & 15.03 & 117.97 \\
\hline Kütahya & 0.00 & 3.81 \\
\hline Manisa & 105.34 & 220.51 \\
\hline Mersin & 56.60 & 146.94 \\
\hline Muğla & 78.98 & 168.14 \\
\hline Şanlıurfa & 160.84 & 378.47 \\
\hline Sivas & 0.00 & 0.00 \\
\hline
\end{tabular}

\section{SONUÇLAR VE ÖNERILER}

Bu çalışma, iklim değişiklğine karşı en hassas bölgelerin başında gelen Akdeniz Havzası içerisinde yer alan [43, 44] Türkiye'de, enerji talebini tahmin etmede kullanılabilen en temel iki parametre olan 1sıtma ve soğutma gün derece sayılarının iklim değişikliğini tek senaryo üzerinden dikkate alarak gelecekte nasıl değişeceğini öngörmeye çalışmıştır. Bu amaçla, iklim değişikliği senaryosu olarak mevcut 
koşulların aynen devam ettiği varsayılarak gelecekteki iki farklı dönem (2016-2035 ve 2046-2065), referans olarak al1nan 1981-2000 geçmiş dönemi ile karşılaştırılmıştır. Modelden alınan sonuçlar analiz edildiğinde, ssıtma gün derece sayılarında tüm ülke genelinde bir azalma ve tam aksi doğrultuda soğutma gün derece sayılarında ise genel olarak bir artış olacağ 1 öngörülmüştür. Isıtma gün derece sayılarındaki azalma yüksek kesimlerde çok daha belirgindir. Bu durum özellikle buraların mevcut koşullarda yükseltiden kaynaklı soğuk olması ve gelecekte iklim değişikliği ile birlikte buraların daha fazla ısınmasıyla ilişkilidir. Özellikle; Toros dağ kuşağı, Küre, Ilgaz, Bolu ve Köroğlu dağlarını içeren Batı Karadeniz dağ kuşağı, Doğu Anadolu'nun neredeyse tamamında 1sıttma gün derecesinde azalış daha belirgindir. Isıtma gün derece sayılarındaki bu azalmanın ve soğutma gün derece sayılarındaki bu artışın 2046-2065 döneminde 20162035 dönemine kıyasla daha fazla olacağı sonucuna varılmıştır. Elde edilen bu bulgular, daha önce Akdeniz Havzası ve Türkiye için yapılan iklim modellemeleri çalışmalarında $[28,45,46]$ elde edilen gelecekte bu bölgelerdeki giderek artan sıcaklık artışı beklentisi ile de örtüşmektedir. Özellikle sıcak mevsimlerde daha fazla olması beklenen artışla birlikte soğutma ihtiyacının daha fazla olacağ mevsim normallerinin üzerine çıkabilecek yeni normallerle birlikte ısıtma ihtiyacının ise azalabileceği bu çalışmanın sonuçları ile bölge iklimi için yapılan öngörüler arasında tutarlı bir ilişki ortaya koymaktadır. Bu durum, Türkiye'nin topografik özellikleri ve etkisinde bulunduğu basınç merkezlerinin etkisi ile açıklanabilir. Isıtma gün derecelerindeki azalma, Türkiye'nin yüksek topografik alanlarında daha kuvvetli bir dağılış sergilemektedir. Bu durum yükseltiden dolayı soğuk olan bölgelerin daha çok ısınacağı sinyalini vermektedir. Diğer yandan yıl içerisinde Azorlar yükseği ile Muson alçağının yılın özellikle yaz mevsiminde etkili olarak bu bölgelerde yaz kuraklığının oluşmasında [47, 48] önemli bir paya sahip olduğu ve Güneydoğu, Akdeniz, Ege, Marmara ve İç Anadolu bölgelerinde, bu basınç merkezlerinin iklim değişikliği kaynaklı etkilerinin kuvvetlenmesi sebebiyle SGD'nin artışını tetiklediği söylenebilir. Özetlemek gerekirse, analiz sonuçları Türkiye'nin sıcaklık klimatolojisinde iklim değişikliğine bağlı olarak daha sıcak normallere girileceğine işaret etmektedir.

Gelecekte 1sıtma gün derece sayısında azalma ve sogutma gün derece sayısında artış beklenirken ortalama s1caklıklardaki artışın doğurduğu bu olağan iki uç değiş̧imin net etkisinin de özellikle beklenen enerji talebini öngörmede titizlikle incelenmesi gerekir. Bu incelemelerin özellikle göç alan şehirlerde yerleşim alanlarının genişlemesiyle artan yakıt tüketimi ve bu nedenle oluşacak kentsel ısı adalarını, yoğun göç alan yerlerde gecekondulaşmanın getirdiği 1sı kaybı yüksek derme çatma evlerin inşasını da dikkate alması gerekmektedir. Ayrıca bölgesel ölçekteki bu uygulamaların dünyanın farklı bölgeleri için de uygulanabilir olması bir başka önemli konudur. Özellikle, enerjiye erişimin sınırlı olduğu sosyo-ekonomik yetersizlikle boğuşan ülkelerde, aşırı soğutma ihtiyacından doğacak klima, vantilatör vb. sogutma araçlarına sahip olabilme yetisinin bulunmamasının doğurabileceği sıkıntılar da farklı altyapılara sahip toplumlar açısından detaylı irdelenmesi gereken konulardan biri olarak karşımıza çıkmaktadır. Benzer şekilde dönemsel olarak enerji talebindeki dalgalanmaların tahmin edilmesinde, 1sıtma ve soğutma cihazlarının arz-talep miktarlarının öngörülerek bu alandaki ticari yatırım ve üretimlerin planlanmasında, 1sıtma ve soğutma gün derecelerinin iklim değişikliği senaryoları kullanılarak öngörülmesi enerji piyasasını doğru yönlendirebilecek çalışmalar olarak literatürdeki yerini alacaktır. Artan nüfus baskısının yanısıra iklim değişikliği etkileri dikkate alındığında gelecekte enerjiye olan talebin artacağı tahmin edilmektedir. Bu nedenle çalışma ayrıca önem taşımaktadır. İklim değişikliğinin ısıtma ve soğutma gün derecelerine etkisini bölgesel bazda ortaya koyan bir çalışma olması nedeniyle, çalışmanın karar vericiler açısından gelecek iklim değişikliği eylem planları ve enerjiye olan talepteki artışa bağlı enerji politikalarının belirlenmesinde başvurulacak bir kaynak olacağı düşünülmektedir.

\section{TEŞEKKÜR}

$\mathrm{Bu}$ çalışma Boğaziçi Üniversitesi Bilimsel Araştırma Projeleri Fonu'nun 13561 No.lu projesince desteklenmiştir.

\section{KAYNAKLAR}

[1] Auffhammer, M., \& Mansur, E. T. (2014). Measuring climatic impacts on energy consumption: A review of the empirical literature. Energy Economics, 46, 522-530.

[2] Mansur, E. T., Mendelsohn, R., \& Morrison, W. (2008). Climate change adaptation: A study of fuel choice and consumption in the US energy sector. Journal of Environmental Economics and Management, 55(2), 175-193.

[3] ASHRAE. (2001). ASHRAE Handbook: Fundamentals. American Society of Heating, Refrigerating and Air-Conditioning Engineers, $544 \mathrm{pp}$.

[4] Badescu, V., \& Zamfir, E. (1999). Degree-days, degree-hours and ambient temperature bin data from monthly-average temperatures (Romania). Energy Conversion and Management, 40(8), 885-900.

[5] Büyükalaca, O., Bulut, H., \& Y1lmaz, T. (2001). Analysis of variable-base heating and cooling degree-days for Turkey. Applied Energy, 69(4), 269-283. 
[6] Christenson, M., Manz, H., \& Gyalistras, D. (2006). Climate warming impact on degree-days and building energy demand in Switzerland. Energy Conversion and Management, 47(6), 671-686.

[7] Matzarakis, A., \& Balafoutis, C. (2004). Heating degree-days over Greece as an index of energy consumption. International Journal of Climatology, 24(14), 1817-1828.

[8] Dombaycı, Ö. A. (2009). Degree-days maps of Turkey for various base temperatures. Energy, 34(11), 1807-1812.

[9] Papakostas, K., Mavromatis, T., \& Kyriakis, N. (2010). Impact of the ambient temperature rise on the energy consumption for heating and cooling in residential buildings of Greece. Renewable Energy, 35(7), 1376-1379.

[10] Al-Hadhrami, L. M. (2013). Comprehensive review of cooling and heating degree days characteristics over Kingdom of Saudi Arabia. Renewable and Sustainable Energy Reviews, 27, 305-314.

[11] Kadığlu, M., Şen, Z., \& Gültekin, L. (1999). Spatial heating monthly degree-day features and climatologic patterns in Turkey. Theoretical and Applied Climatology, 64(3-4), 263269.

[12] Bahadır, M. (2013). Türkiye'de 1sınma ve soğutma gün derecelerine Afyonkarahisar örneği. Coğrafyacılar Derneği Yıllık Kongresi, 19-21 Haziran 2013, İstanbul.

[13] Cartalis, C., Synodinou, A., Proedrou, M., Tsangrassoulis, A., \& Santamouris, M. (2001). Modifications in energy demand in urban areas as a result of climate changes: an assessment for the southeast Mediterranean region. Energy Conversion and Management, 42(14), 1647-1656.

[14] Hadley, S. W., Erickson, D. J., Hernandez, J. L., Broniak, C. T., \& Blasing, T. J. (2006). Responses of energy use to climate change: A climate modeling study. Geophysical Research Letters, 33(17).

[15] Benestad, R. (2008). Heating degree days, cooling degree days, and precipitation in Europe: analysis for the CELECT-project. Report for the Norwegian Metereoroligical Institute.

[16] Xu, P., Huang, Y. J., Miller, N., Schlegel, N., \& Shen, P. (2012). Impacts of climate change on building heating and cooling energy patterns in California. Energy, 44(1), 792-804.

[17] Zhou, Y., Eom, J., \& Clarke, L. (2013). The effect of global climate change, population distribution, and climate mitigation on building energy use in the US and China. Climatic Change, 119(3-4), 979-992.

[18] Wang, H., \& Chen, Q. (2014). Impact of climate change heating and cooling energy use in buildings in the United States. Energy and Buildings, 82, 428-436.

[19] Sailor, D. J. (2001). Relating residential and commercial sector electricity loads to climate- evaluating state level sensitivities and vulnerabilities. Energy, 26(7), 645-657.

[20] Pardo, A., Meneu, V., \& Valor, E. (2002). Temperature and seasonality influences on Spanish electricity load. Energy Economics, 24(1), 55-70.
[21] Valor, E., Meneu, V., \& Caselles, V. (2001). Daily air temperature and electricity load in Spain. Journal of Applied Meteorology, 40(8), 1413-1421.

[22] Martinaitis, V. (1998). Analytic calculation of degree-days for the regulated heating season. Energy and Buildings, 28(2), 185-189.

[23] OrtizBeviá, M. J., Sánchez-López, G., Alvarez-Garcìa, F. J., \& RuizdeElvira, A. (2012). Evolution of heating and cooling degree-days in Spain: trends and interannual variability. Global and Planetary Change, 92, 236-247.

[24] Coşkun, M., Gürkan, H., Arabacı, H., Demircan, M., Eskioğlu, O., Şensoy, S.,Yazıcı, B. (2016). İklim değişikliğinin enerji tüketimine etkisi. 10.Uluslararası Temiz Enerji Sempozyumu (UTES), 24-26 Ekim 2016, İstanbul.

[25] TÜİK. (2013). Nüfus projeksiyonları, 2013-2075. http://www. tuik.gov.tr/PreHaberBultenleri.do?id=15844

[26] Tatli, H., Dalfes, H. N., \& Menteş, Ş. S. (2004). A statistical downscaling method for monthly total precipitation over Turkey. International Journal of Climatology, 24(2), 161-180.

[27] Gosling, S. N., Dunn, R., Carrol, F., Christidis, N., Fullwood, J., Gusmao, D. D., ... \& Kennedy, J. (2011). Climate: Observations, projections and impacts. The United Kingdom: Met Office.

[28] Turp, M. T., Öztürk, T., Türkeş, M., \& Kurnaz, M. L. (2014). RegCM4.3.5 Bölgesel iklim modelini kullanarak Türkiye ve çevresi bölgelerin yakın gelecekteki hava sıcaklığı ve yağış klimatolojileri için öngörülen değişikliklerin incelenmesi. Ege Coğrafya Dergisi, 23(1), 1-24.

[29] Tatli, H. (2015). Downscaling standardized precipitation index via model output statistics. Atmósfera, 28(2), 83-98.

[30] Pal, J. S., Giorgi, F., Bi, X., Elguindi, N., Solmon, F., Rauscher, S. A., Gao, X., Francisco, R., Zakey, A., Winter, J., Ashfaq, M., Syed, F. S., Sloan, L. C., Bell, J. L., Diffenbaugh, N. S., Karmacharya, J., Konaré, A., Martinez, D., Da Rocha, R. P., Steiner, A. L. (2007). Regional climate modeling for the developing world: the ICTP RegCM3 and RegCNET. Bulletin of the American Meteorological Society, 88(9), 13951409.

[31] Taylor, K. E., Stouffer, R. J., Meehl, G. A. (2012). An overview of CMIP5 and the experiment design. Bulletin of the American Meteorological Society, 93(4), 485-498.

[32] Van Vuuren, D. P., Edmonds, J., Kainuma, M., Riahi, K., Thomson, A., Hibbard, K., Hurtt, G. C., Kram, T., Krey, V., Lamarque, J. F., Masui, T., Meinshausen, M., Nakicenovic, N., Smith, S. J., Rose, S. K. (2011). The representative concentration pathways: an overview. Climatic Change, 109, 5-31.

[33] Riahi, K., Gruebler, A., and Nakicenovic, N. (2007). Scenarios of long-term socio-economic and environmental development under climate stabilization. Technological Forecasting and Social Change, 74 (7), 887-935.

[34] Ovo Energy. (2018). How much energy do you use to heat your home? https://www.ovoenergy.com/guides/energy-guides/how-much-heating-energy-do-you-use.html 
[35] Day, T. (2006). Degree-days: theory and application. The Chartered Institution of Building Services Engineers, London, 106.

[36] EIA. (2016). Energy Units and Calculators Explained: Degree-Days. http://www.eia.gov/energyexplained/index.cfm?page=about_degree_days

[37] Aceituno, P. (1979). Statistical formula to estimate heating or cooling degree-days. Agricultural Meteorology, 20(3), 227232.

[38] Ahrens, C. D. (2012). Essentials of Meteorology: An Invitation to the Atmosphere, 6th Edition. The United States of America: Brooks/Cole Cengage Learning.

[39] Bromley, M. (2009). Degree Days: Understanding Heating and Cooling Degree Days.

http://www.degreedays.net/introduction

[40] TÜİK. (2015). İllerin aldığı, verdiği göç, net göç ve net göç hız1, 1980-2015. http://www.tuik.gov.tr/PreIstatistikTablo. do?istab_id $=1595$

[41] Kültür ve Turizm Bakanlığı. (2015a). Tesis istatistikleri. http:// yigm.kulturturizm.gov.tr/TR,9859/tesis-istatistikleri.html
[42] Kültür ve Turizm Bakanlığı. (2015b). İllere göre sit alanları istatistiği. http://www.kulturvarliklari.gov.tr/TR,44974/illere-gore-sit-alanlari-istatistigi.html

[43] Giorgi, F. (2006). Climate change hot-spots. Geophysical Research Letters, 33(8), 1-4.

[44] Giorgi, F., \& Lionello, P. (2008). Climate change projections for the Mediterranean region. Global and Planetary Change, 63(2), 90-104.

[45] Turp, M. T., Ozturk, T., Türkeş, M., \& Kurnaz, M. L. (2015). Assessment of projected changes in air temperature and precipitation over the Mediterranean region via multi-model ensemble mean of CMIP5 models. Journal of the Black Seal Mediterranean Environment, Special Issue (21), 93-96.

[46] Ozturk, T., Ceber, Z. P., Türkeş, M., \& Kurnaz, M. L. (2015). Projections of climate change in the Mediterranean Basin by using downscaled global climate model outputs. International Journal of Climatology, 35(14), 4276-4292.

[47] Akbaş, A. (2014). Türkiye'de klimatolojik kuraklık olasılıklarının dağılışı. Türk Coğrafya Dergisi, 63, 1-7.

[48] Akbaş, A. (2014). Türkiye üzerindeki önemli kurak yıllar. Coğrafi Bilimler Dergisi, 12(2), 101-118. 